\title{
Impact of water scarcity on Agriculture in Mi Oya River Basin
}

\section{G.V.H.M' Madumali, M.M.S.B ${ }^{2}$ Manamperi}

Department of Geography, University of Sabaragamuwa

Department of Fine Arts, University of Kelaniya.

maheshikausjp@gmail.com

\begin{abstract}
There is a finite amount of fresh water on earth and only $3 \%$ of the total water in the world is freshwater while less than $1 \%$ is readily usable by humans. Water availability varies in time and space. One river basin may be suffering extended drought while neighbouring river basins may be experiencing devastating floods. Water scarcity can be defined as a lack of sufficient water or not having access to safe water supplies. When considering the situation in the Mi Oya river basin, clearly it can be identified water scarcity in this area as mentioned by the definition. Therefore, the purpose of the study is, identify the impacts of water scarcity on agriculture while introducing mitigation methods to the recognized impacts. Accordingly, research problems seek answers for the questions of what are the main fields of agriculture affected by water scarcity and to which extent it impacts agricultural activities in this area. The main objective of the study is to identify the impact of water scarcity on agriculture in the Mi Oya river basin. Both qualitative and quantitative methods were used for data collection through questionnaires, structural and semi-structural interviews, and case studies. As well as a mixed method of descriptive and analytical have been applied for the data analysis and discussion. Accordingly, results proved that paddy cultivation as the main field affected due to water scarcity and at least one season or abandon because of the insufficient water in the area. Therefore, people have to use adaptive methods for water scarcity. Finally, can be concluded that it is very important to recognize these kinds of impacts as we are having an agricultural economy and because of water scarcity considered as a global crisis around the world.
\end{abstract}

Keywords: Water scarcity, Agriculture, Impacts, Mi Oya River Basin 


\section{Introduction}

Water is essential for agricultural production and food security. It is the lifeblood of ecosystems, including forests, lakes, and wetlands, on which the food and nutritional security of present and future generations depend. Water is becoming increasingly scarce worldwide. (Pereira et al., 2002a). Accordingly, water scarcity can be defined as, a lack of sufficient water or not having access to safe water supplies. Aridity and droughts are the natural causes of scarcity. More recently, man-made desertification and water shortages are aggravating the natural scarcity while the population is growing and the demand for water faces an increased competition among water user sectors and regions. Not only rainfall is not enough abundant in many regions, thus limiting the number of water resources available, but also the quality of water is increasingly degraded making that water resources unavailable for more stringent requirements. Agriculture is therefore forced to find new approaches to cope with water scarcity but adopting sustainable water use issues (Pereira, 2005). Agriculture is both a cause and a victim of water scarcity. The excessive use and degradation of water resources are threatening the sustainability of livelihoods dependent on water and agriculture. As water becomes scarcer, it is fundamentally important to tackle the issue head-on. (FAO,2016).

Mi Oya is a stream in the North-Western province in Sri Lanka. The basin area of Mi Oya an approximately $1530 \mathrm{~km}^{2}$ and the total length is about $118 \mathrm{~km}$. The major tributary is called Nanneriya Oya. It contributes about $40 \%$ of the total runoff of the main river. Climatically the Mi Oya upper watershed gets about $1200 \mathrm{~mm}$ as annual rainfall. It has great variation according to the season. The annual rainfall of the major rain season of the area reports about $1200 \mathrm{~mm}$ while in the minimum rain period it will be about $840 \mathrm{~mm}$. 


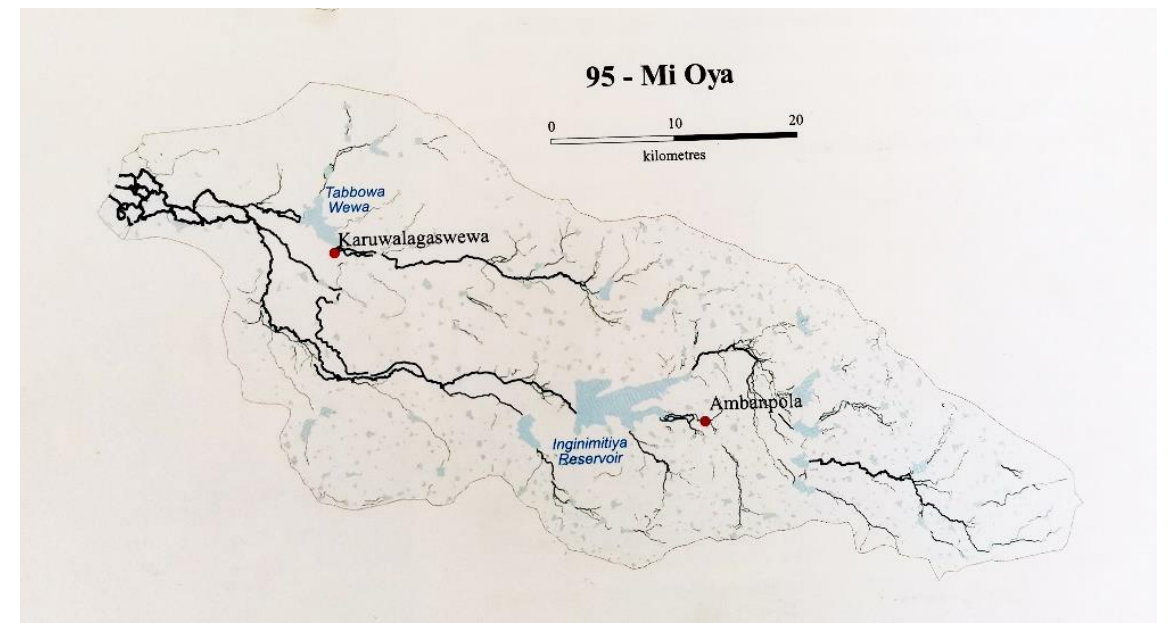

Fig 1.1. Map of Mi Oya River Basin

Under the Mi Oya project of irrigation, all highland area in Kurunegala District has been cultivated under the contribution of the water stored in those sub tanks. Due to the climatic variation of the area, agriculture has been largely affected. Therefore, the study focused on the impacts of water scarcity on agriculture in the Mi Oya river basin. Accordingly, research questions seek answers for questions of,

$>$ What are the main agricultural activities affected by water scarcity?

$>$ To which extent it impacts agricultural activities?

$>$ How it affects people's lives?

Due to water is an essential factor for agriculture, it is very important to managing water efficiently and equitably with a proper mechanism to overcome the issues regarding water scarcity and agriculture. Therefore, the main objective of the study can be formulated as;

> Identify the impact of water scarcity on agriculture in the Mi Oya river basin.

$>$ Introduce proper strategies to overcome the identified impacts.

Due to having an agriculturally based economy and being a developing country, it is very important to recognize issues related to water scarcity and agriculture in Sri Lanka. Despite water is an essential factor for agriculture, water scarcity has become 
great issue in many areas of the country. Because of lacking sufficient water, agricultural activities have been ruined and productivity becomes a loss. Due to that, economic loss can appear. Therefore, needs to be recognized the impact of water scarcity on agriculture while taking actions to mitigate the issues that have been identified. Otherwise, it will impact the whole economy of the country.

\section{Materials and Methods}

\subsection{Population and Sampling}

Altogether there were 112 families which were doing agriculture as their main livelihood activity. Among them, 50 families have been selected as the sample of the research by using snowball sampling.

\subsection{Data Collection and Data Analysis}

This study is dependent on primary and secondary data, which has been collected by using the below-mentioned method.

\begin{tabular}{|l|l|}
\hline Primary data collection methods & Secondary data collection methods \\
\hline$>$ Observation & $>$ Maps \\
$>$ Informal discussions & $>$ Satellite images \\
$>$ Questioners & $>$ Aerial photographs \\
$>$ photographs & $>$ Web sources \\
& $>$ Institutional reports \\
\hline
\end{tabular}

Table 2.1. Data collection methods

Due to the collected data belongs to the qualitative category, descriptive data analytical method has been used to data analysis in this study.

\subsection{Study Area}

Palukadawala area is located in sub-locality, Galgamuwa DSD in Kurunegala District, North Western Province. The Palukadawala tank is covered by an area of 3042672.31 acres and the perimeter of this tank is 10448.32 acres. Accordingly, there are many 
land-use patterns around the Palukadawala area. Paddy Field, Home Garden, and Scrub are mainly can be seen. As well as some Marshy lands and rock lands and coconut plantation lands also can be seen in this area.

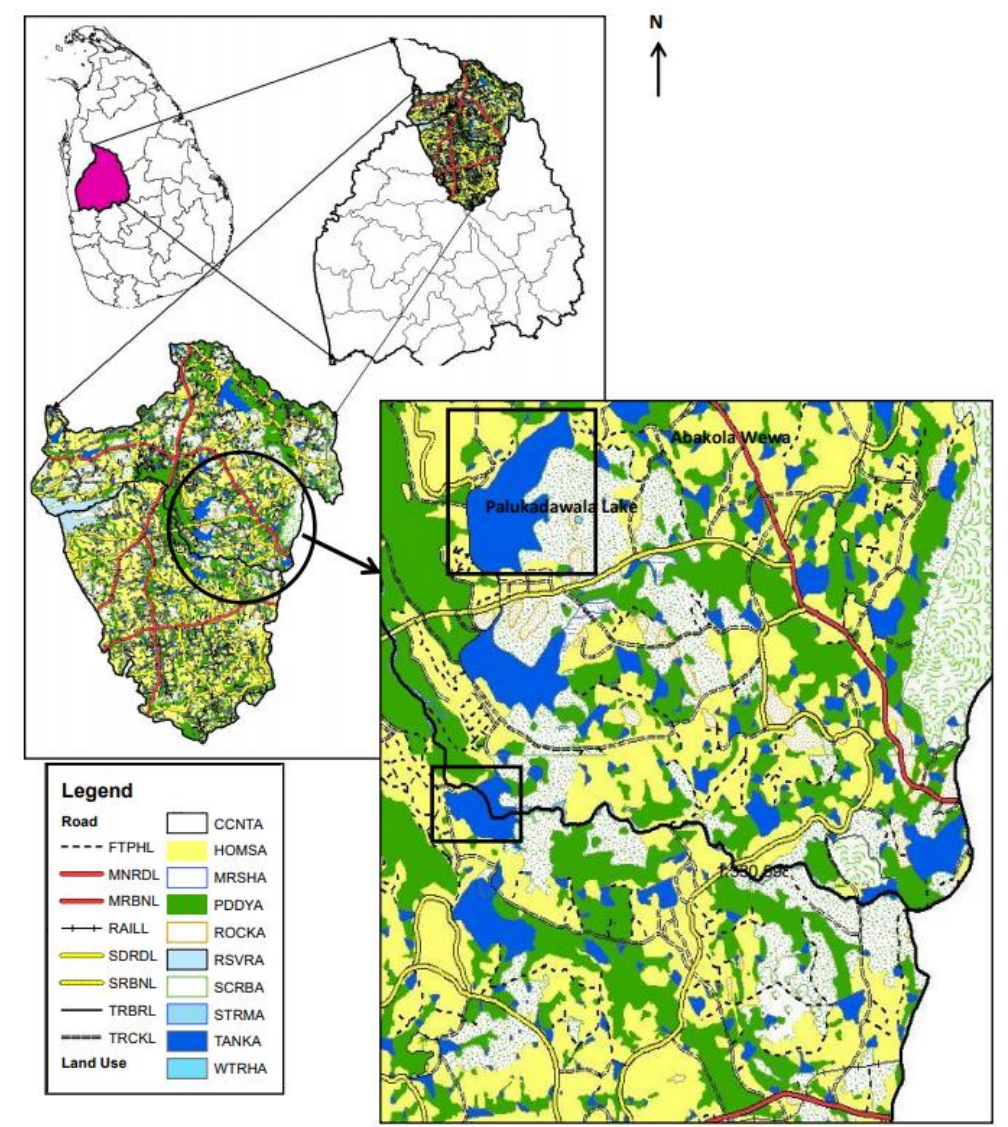

\section{Results and discussion}

The impact of water scarcity on agriculture in this area has been identified from several perspectives as the data collected is based on three main tanks as Koan wewa, Maha wewa and Lokurugama wewa. 


\begin{tabular}{|l|c|c|c|}
\hline \multirow{2}{*}{ Tank } & \multirow{2}{*}{ Extent(Ac.) } & \multicolumn{2}{|c|}{ Water Level } \\
\cline { 3 - 4 } & & $\begin{array}{c}\text { Current water } \\
\text { level }\end{array}$ & $\begin{array}{c}\text { Original water } \\
\text { level }\end{array}$ \\
\hline Koan Wewa & $16 \mathrm{Ac}$ & $1^{\prime}$ & $8^{\prime}$ \\
\hline Maha Wewa & $50 \mathrm{Ac}$ & $10^{\prime}$ & $20^{\prime}$ \\
\hline Lokurugama & $16 \mathrm{Ac}$ & $1^{\prime}$ & $10^{\prime}$ \\
\hline
\end{tabular}

Table:3.1. The water level of the Tanks

The villagers who are in the Ihallawattha area do their paddy cultivation based on these tanks. The chart shows that there is a huge gap between the current water level and the original water level. As an example, the capacity of the Koan Wewa is about $8^{\prime}$. But the current water level is only about $1^{c e}$. As a percentage it is a reduction of $87.5 \%$. When it comes to Lokurugama wewa it has a total capacity of $10^{\text {ee }}$ but now the reduction is about $90 \%$. Maha wewa which is the largest with a capacity of about 20ft. shows at least a half of water reduction. The total capacities of these three tanks are about 38 feets, but when considering the present situation there are only 12 feet left. Changing the pattern of the rainfall, the higher amount of groundwater seepage in the dry zone, and the high evaporation and transpiration are the main issues that cause the decreasing the water levels in the tanks.

\begin{tabular}{|c|c|c|c|c|c|}
\hline \multirow{3}{*}{ Tank } & \multirow{3}{*}{ Extent(Ac.) } & \multicolumn{4}{|c|}{ Functionary } \\
\hline & & \multicolumn{3}{|c|}{ Working } & \multirow{2}{*}{ Abandon } \\
\hline & & Yala & Maha & Both & \\
\hline Koan Wewa & $16 \mathrm{Ac}$ & $\sqrt{ }$ & $\sqrt{ }$ & - & $\sqrt{ }$ \\
\hline Maha Wewa & $50 \mathrm{Ac}$ & $\sqrt{ }$ & $\sqrt{ }$ & $\sqrt{ }$ & $\sqrt{ }$ \\
\hline Lokurugama & $16 \mathrm{Ac}$ & - & $\sqrt{ }$ & - & $\sqrt{ }$ \\
\hline Total & 84Ac. & & & & \\
\hline
\end{tabular}

Table:3.2. The functionality of the Tanks 
There have 03 main seasons including Yala, Maha, and intermediate season. Maha is the significant season that can be highlighted in this area. Comparing with the other season Yala is the other prominent and well productive season according to them. As well there have been so many abandon lands regarding paddy cultivation. Those are located very adjacently to those tanks. At this time there hasn't sufficient water capacity to cultivate their in-land, especially the paddy lands. Due to that case, the productivity of the paddy lands has been decreased. Closer to the Koan Wewa, Maha Wewa and the Lokurugama have the same portion of abandoned lands. These days they do cattle rearing in those lands. That is a very significant fact in the study area during the dry zones without rain or any water left in the tanks.

\subsection{Paddy land use pattern in Palukadawala area}

There four main paddy lands were identified such as Koan wewa, Lokurugama wewa, Moragas wewa, and Ihala Netthipola wewa. The subtotal of these four main investigated land areas is $170 \mathrm{Ac}$ while the abandoned portion has been identified as nearly half of the total extent. At the current use of the paddy, land area is lesser than in the past because of deficiency of enough water.

\begin{tabular}{|c|c|c|c|c|c|c|c|}
\hline \multirow{2}{*}{ No. } & \multirow{2}{*}{ Site name } & \multirow{2}{*}{$\begin{array}{l}\text { Extent } \\
\text { (Ac.) }\end{array}$} & \multicolumn{3}{|c|}{ Current use } & \multirow{2}{*}{$\begin{array}{c}\text { Abandoned } \\
\text { Potion } \\
\text { (Ac.) }\end{array}$} & \multirow{2}{*}{$\begin{array}{l}\text { Reasons for } \\
\text { Abandonce }\end{array}$} \\
\hline & & & Full & Half & Partial & & \\
\hline \multicolumn{8}{|c|}{ Paddy Land } \\
\hline 1 & Koan Wewa & 25 & - & - & $\sqrt{ }$ & 20 & $\begin{array}{c}\text { Haven't enough } \\
\text { water }\end{array}$ \\
\hline 2 & $\begin{array}{l}\text { Lokurugama } \\
\text { Wewa }\end{array}$ & 15 & - & $\sqrt{ }$ & - & 15 & $\begin{array}{c}\text { Haven't enough } \\
\text { water }\end{array}$ \\
\hline 3 & $\begin{array}{l}\text { Mora gas } \\
\text { wewa }\end{array}$ & 100 & - & $\sqrt{ }$ & - & 35 & $\begin{array}{l}\text { Haven't enough } \\
\text { water and labour }\end{array}$ \\
\hline 4 & $\begin{array}{l}\text { Ihala } \\
\text { Netthipola } \\
\text { wewa }\end{array}$ & 30 & - & $\sqrt{ }$ & - & 10 & $\begin{array}{c}\text { Haven't enough } \\
\text { water }\end{array}$ \\
\hline Total & & 170Ac. & & & & 80Ac. & \\
\hline
\end{tabular}

Table:3.3 Paddy land use pattern in Palukadawala area 


\begin{tabular}{|c|c|c|c|c|c|c|c|}
\hline \multirow{2}{*}{ No. } & \multirow{2}{*}{ Site name } & \multirow{2}{*}{$\begin{array}{l}\text { Extent } \\
\text { (Ac.) }\end{array}$} & \multicolumn{3}{|c|}{ Current use } & \multirow{2}{*}{$\begin{array}{l}\text { Abandoned } \\
\text { Potion } \\
\text { (Ac.) }\end{array}$} & \multirow{2}{*}{$\begin{array}{l}\text { Reasons for } \\
\text { Abandoned }\end{array}$} \\
\hline & & & Full & Half & Partial & & \\
\hline \multicolumn{8}{|c|}{ Homestead } \\
\hline 1 & $\begin{array}{l}\text { Koan Wewa } \\
\text { (Banana, } \\
\text { chilies, Papaw, } \\
\text { Buck-wheat) }\end{array}$ & 2 & - & $\sqrt{ }$ & - & $1 / 2$. & $\begin{array}{l}\text { Haven't enough } \\
\text { water }\end{array}$ \\
\hline 2 & Ataragalla & $11 / 2$ & - & $\sqrt{ }$ & - & 1 & Lack of technology \\
\hline 3 & Bathiyagamuwa & 2 & $\sqrt{ }$ & - & - & $1 / 2$ & $\begin{array}{l}\text { Haven't enough } \\
\text { water }\end{array}$ \\
\hline 4 & Polpitigama & 1 & - & - & $\sqrt{ }$ & $1 / 2$ & $\begin{array}{l}\text { Haven't enough } \\
\text { water }\end{array}$ \\
\hline Total & & $6.5 \mathrm{Ac}$. & & & & & \\
\hline
\end{tabular}

Table3.4. Homestead land use pattern in Palukadawala area

Here also shown that the total extent is 6.5 Acres. Among them, more than half $(4.5$ Ac) have been abandoned because of not having enough water.

\section{Conclusion and Recommendation}

As water scarcity becomes a devastating issue in this area, human levies have been ruined day by day. Because the main livelihood activity of the people is paddy cultivation and that is the main field largely affected by the deficiency of water. Despite three seasons, only one season has to cultivate by farmers and cultivation has become nonprofitable because of the use of brackish water. Due to the above problems, crop failures can be identified in this area. Most paddy area has become fallow land due to lack of water while six tanks are partially utilized. Accordingly, nearly half of the total paddy area has been neglected by the farmers due to water scarcity. In addition to the water scarcity, lack of enough labour and lack of technology also partially influenced the agriculture of the area.

By going through the conclusion, it can be recommended that,

Identify additional water resources 
$>$ Changing to minimum water required cultivation

$>$ Identify environmental conservation methods for improper land uses

$>$ Legal actions and awareness program

$>$ Maintain proper hydrological system

Framers are engaging with the agricultural activities at the moment can be identified as a limitation of the research. Due to that, some factors couldn't explain by them clearly. The possible application of the research can be identified from several perspectives. For better institutional arrangement and the study purpose, the research can be applied. In addition to that, identify the impact of water scarcity from the root level this can be used further.

\section{References}

Bandaranayake, G.M, 2007. Water Resources Study; Theory Practice and Application. Colombo: Godage International Publishers.

Mendis, D.L.O (2002). Water heritage of Sri Lanka. Colombo: Sri Lanka Pugwash Group.

Oweis, T., \& Zhang, H. (1998). Water-use efficiency: Index for optimising supplemental irrigation of wheat in water scarce areas. Zeitschrift f. Bewaesserungswirtschaft, 321-336.

Pereira, L. (2005). Water and Agriculture: Facing Water Scarcity and Environmental Challenges. Agricultural Engineering International: The CIGR Journal of Scientific Research and Development, VII.

Pereira, L.S, Cordery, I., \& Lacovides, I. (2002). Coping with Water Scarcity (6th ed.). Paris: UNESCO IHP.

Retrieved 11 February 2021, from

http://unesdoc.unesco.org/images/0012/001278/127846e.pdf

Survey Department of Sri Lanka. (2007). The National Atlas of Sri Lanka (2nd ed.). Colombo. Committee on Agriculture (COAG). (2007). Agriculture and Water Scarcity: a Programmatic Approach to Water Use Efficiency and Agricultural Productivity Comparing notes on institutions and policies. Colombo: IWMI. 
Food and Agriculture Organization of the United Nations. (2003). Review of world water resources by country. Rome.

Gleick, P. (1998). WATER IN CRISIS: PATHS TO SUSTAINABLE WATER USE. Ecological Applications, 8(3), 571-579. doi: 10.1890/10510761(1998)008[0571:wicpts]2.0.co;2

Hanjra, M., \& Qureshi, M. (2010). Global water crisis and future food security in an era of climate change. Food Policy, 35(5), 365-377. doi: 10.1016/j.foodpol.2010.05.006

Shah, T., Hussain, I., \& Rehman, S. (2000). Irrigation management in Pakistan and India. Colombo, Sri Lanka: International Water Management Institute.

United Nations Convention to Combat Desertification (UNCCD). (2011). Water Scarcity and Desertification. UNCCD Thematic Factsheet series. Bonn: UNCCD.

Water for food, water for life: a comprehensive assessment of water management in agriculture. (2007). Choice Reviews Online, 45(02), 45-0867-45-0867. doi: 10.5860/choice.45-0867 